University of Warwick institutional repository

This paper is made available online in accordance with

publisher policies. Please scroll down to view the document

itself. Please refer to the repository record for this item and our

policy information available from the repository home page for

further information.

To see the final version of this paper please visit the publisher's website. Access to the published version may require a subscription.

Author(s): Matthew Watson

Article Title: Trade Justice and Individual Consumption Choices:

Adam Smith's Spectator Theory and the Moral Constitution of the Fair

Trade Consumer

Year of publication: 2007

Link to published version:

http://dx.doi.org/10.1177/1354066107076957

Publisher statement: None 
Trade Justice and Individual Consumption Choices:

Adam Smith's Spectator Theory and the Moral Constitution of the Fair Trade Consumer

Matthew Watson

Published in the European Journal of International Relations, 13 (2), 2007, 263-288. 


\title{
Trade Justice and Individual Consumption Choices: Adam Smith's Spectator Theory and the Moral Constitution of the Fair Trade Consumer
}

\author{
MATTHEW WATSON \\ University of Birmingham, UK
}

\begin{abstract}
A consistent theme of the existing literature is that fair trade consumption practices represent acts of justice. In this article I investigate such an equation from the perspective of the moral theory of Adam Smith. Smith explains the development of moral sensibilities via an imaginative act he calls 'sympathy'. For Smith, justice prevails in interpersonal relationships in which the potential for one person to do harm to another is ruled out because their respective imaginations are in perfect accord, thus creating a situation of mutual sympathy. I advance two main conclusions. First, I argue that fair trade consumption is undoubtedly a moral act in the manner described by Smith, as it involves consumers responding to fair trade campaigns in order to trigger their moral sensibilities through exercising their imaginative faculties. Second, though, I argue that fair trade consumption is not specifically a moral act of justice in the manner described by Smith. The structure of fair trade invites the First World consumer to display sympathy for the Third World producer, but it provides no means for that sympathy to be reciprocated. As such, instances of genuine mutual sympathy do not arise. From a Smithian perspective, fair trade consumption practices are an act of beneficence rather than an act of justice. They thereby reside in the realm of private virtue rather than the realm of public duty, with significant implications for the way in which trade justice is conceptualised and studied in IPE.
\end{abstract}

Key words: Adam Smith; fair trade; sympathy; impartial spectator; justice; beneficence. 
There has been a marked increase in recent years in First World consumption of Third World products carrying the Fair Trade label. According to the large-scale surveys undertaken of such consumers (e.g., Shaw and Shiu, 2002), in almost all instances this is a conscious decision which is designed to encapsulate an affirmative action. With very few exceptions, individuals become fair trade consumers knowingly, and they do so with the explicit intention of expressing some degree of solidarity with the Third World producers of the products they consume. The issue of fair trade is very much an issue of international politics, in that its whole essence rests on the premise that the moral dimensions of modern exchange relationships extend beyond and across national borders. This suggests that it is a moral act to purchase a product which allows a distant stranger to enjoy a more comfortable lifestyle simply by being recognised as 'the producer' of that product.

Moreover, much of the existing academic literature on fair trade names that moral act specifically as one of justice (e.g., Raynolds, 2002; Hudson and Hudson, 2003; Renard, 2003; Goodman, 2004). It is the task of later sections to decide whether such a characterisation is appropriate. Even if it is, however, it still does not tell us exactly how cross-border justice claims of this nature are internalised by consumers in the first place. A post hoc examination of consumption practices might well reveal the satisfaction of justice claims in the purchase of fair trade products, but how do consumers come to sense the initial need to act justly?

The issue is to explain why some people buy fair trade but others of similar affluence and social circumstances do not. As such, the decision to be a fair trade consumer appears to relate less to the general moral principles in evidence within a society and more to the development of a particular moral psychology amongst certain individuals. It is for this reason that I set the following analysis within the 
context of the philosophical work of Adam Smith and, in particular, that of his Theory of Moral Sentiments (Smith 1982 [1759]).

Smith prioritises individual motivation in his explanation of moral being (Montes, 2004: 112). As such, it is the active aspect of making moral choices that matters to him (Mitchell, 1987: 420). Moral actions cannot be understood for Smith without first identifying the precise nature of the virtue that influenced the action. He understands individuals as being constantly involved in social situations in which they have to decide whether a harm has been done or a good is absent, before then being required to make a further decision about how best to respond to that initial judgement via the affirmation of a particular virtue. If the decision is that a harm has to be negated, then the response requires an act of public duty, and for Smith justice is the most common manifestation of such acts. By contrast, if the decision is that moral behaviour is compensating for the absence of a good, then the response requires an act of private beneficence, and public duty is not involved in the individual's moral calculations.

The manner of Smith's moral reflections is therefore justification in itself for choosing his work as the starting point for my discussion of the ethics of fair trade consumption. Moreover, the return to Smith is further warranted in this instance, because fair trade works within the structures of market exchange (Watson, 2006), thereby reinforcing their dominance, and Smith's moral theory was designed specifically to understand the ethics of market society. My argument proceeds in three stages. In section one, I analyse Smith's description of the way in which the individual internalises a specific moral psychology. I pay particular attention to the link that he posits between acts of the imagination, the desire to be judged as having behaved sympathetically and the development of moral dispositions. In section two, I 
show that both the political energies of fair trade campaigners and the marketing of fair trade products are aimed at inducing imaginative acts in the minds of potential consumers. They are designed to create vicarious, albeit only ever one-way, relationships between imaginatively active First World consumers and the Third World producers of fair trade products. In section three, I explore the potential limits of such relationships and, by extension, the limits of the success of fair trade as a development strategy based on the satisfaction of justice claims. These arise from Smith's concern that sympathy requires intimacy and that, as such, there are psychological constraints on initiating imaginatively induced sympathetic relationships across both physical and social distance.

I conclude that this problem may not be completely insurmountable in practice, as it can be shown that the decision to prioritise the consumption of fair trade products conforms very much to what Smith had in mind as a moral act. However, from a Smithian perspective the content of that moral act is not justice. I do not rule out the possibility of being able to draw such a connection by using the alternative conceptual frameworks of other moral theorists, but the connection does not exist when starting with Smith. This is important, because the equation of fair trade purchases and acts of justice has been crucial to the dynamism of the fair trade campaign, which perhaps explains why it has also been reflected so consistently in the academic literature on the subject. Nonetheless, from a Smithian perspective it appears to be beneficence rather than justice that serves as the moral basis for the practice of fair trade. Using Smith's account of the way in which the individual develops particular moral dispositions, First World consumers’ fair trade consumption decisions are triggered by private virtue rather than by public duty. They counteract the absence of a good in the broad sphere of Third World development rather than 
preventing a harm being enacted on specific Third World producers. I finish by reviewing the implications of my analysis for how to conceptualise trade and the corresponding conditions for trade justice within IPE.

\section{Smith, the Impartial Spectator and the Social Basis of the Moral Imagination}

In order to investigate the possibility of deriving a Smithian perspective on the moral psychology of fair trade consumers, it is important to start with an overview of his broader analysis of the internalisation of moral dispositions as a whole. For Smith, the key to understanding how individuals choose to act lies in understanding the interpretive processes which precede the commitment to the act itself. Action cannot be condensed merely into the moment of its execution. That moment also has a significant pre-history of reflection and contemplation, which in turn are rooted in the human cognitive and communicative capacities that make life in society possible.

The moral system that Smith attempts to elucidate is one that is based on observation of everyday human interaction (Mitchell, 1987: 406; Khalil, 1998: 21920). For, it is through those interactions that individuals learn more about who they are and what they want out of life. As Jack Russell Weinstein notes (2006: 4), 'The Theory of Moral Sentiments offers an eighteenth-century psychology that mixes moral development with identity construction and self-awareness'. Moral judgements have an irreducibly social content for Smith (Morrow, 1989 [1928]), such that moral conduct arises from individuals' relationships with other members of the society in which they live (Smith, 1982 [1759]: II.ii.3.1, II.2.6). 
Smith employs his famous mirror metaphor (ibid: III.1.3) to argue that the individual is constituted as a human being only by the presence of other people. He suggests that we would have little knowledge of our physical make-up were it not for the ability to view ourselves in a mirror. From this simple starting position, he proceeds to depict society as an equivalent phenomenon, because it is only through observing other people's responses to our actions that we gain any knowledge of our moral make-up. As Jan Peil puts it (1999: 86), for Smith 'man is an individual subject by virtue of his relationship with other human beings'. Moral thought and moral action are therefore the products of an intersubjectively shared series of life experiences. To be conscious of the need to make a decision is to reflect upon what other people might think having been witness to the outcomes of that decision (Bridel and Salvat, 2004: 134).

On this basis, Daniel Fusfeld describes Smith’s position (2002: 24) as 'an early 'other-directed' theory of human action'. However, whilst this points us in the right direction, I stop short of endorsing such a view. Taken literally, it suggests some sort of innate inclination for individuals to prioritise other people's concerns over their own. Yet, this is to overlook Smith's invocation of the Stoic principle of oikeiōsis (Berry, 2004: 458) to assist his bald assertion that every person 'is first and principally recommended to his own care' (Smith 1982 [1759]: VI.ii.1.1). It also distracts our attention from his continual hinting that human motives are always complex and multiple. Preferable in this regard, then, is Weinstein's argument (2006: 4) that Smith was attempting to forward 'an early understanding of what is now termed a relational self’.

The concept of a relational self helps to solve a fundamental problem in explaining the derivation of moral dispositions from the perspective of individual 
psychology. Smith is adamant (1982 [1759]: I.i.3.1) that social harmony ensues only in circumstances in which the moral sentiments of the observer of an event are fully compatible with the sentiments that the event induced in the person who was most directly affected by it. In other words, whatever emotion the event caused the person principally concerned to feel, the observer has to be able to convince themselves that the emotive response was both appropriate in scale and judicious in its enactment. This corresponds to a situation that Smith describes as mutual sympathy: fully reciprocated fellow-feeling at the emotional level (ibid: I.i.2). Such a situation emerges when the observer sympathises with the person principally concerned on recognition of the latter's response being commensurable with the social situation in which they found themselves, at the same time as the person principally concerned sympathises with the observer's affirmation that their response was justified.

Yet, how does this instance of mutual sympathy materialise? Smith provides an important clue when he states (ibid: I.i.1.10) that sympathy 'does not arise so much from the view of the passion, as from that of the situation which excites it'. The two individuals, observer and observed, remain resolutely separate from one another. However, a sympathetic relationship can strike up between the two, because each can appreciate through familiarity the context in which the other is called upon to play their role of either observer or observed. They cannot physically become the other person, and nor can they truly be sure what the other person must be feeling. But they can summon the memory of their previous life experiences in order to get a fairly clear picture, via the imagination, of how they would feel were they to find themselves in the other person's situation. In Smith’s words (ibid: I.i.1.2), 'our senses will never inform us of what he [the other person] suffers. They never did, and never 
can, carry us beyond our own person, and it is by the imagination only that we can form any conception of what are his sensations’.

As Luc Boltanski has argued (1999: 40-1), for Smith the single act of observation implies two different, albeit simultaneous, spectatorial moments. The relational self divides into an empirical and an ideal spectator (Smith, 1982 [1759]: III.1.6). It is the empirical spectator who physically undertakes the observation of the event, and whose role as witness creates the context in which a sympathetic response is called for. The ideal spectator, by contrast, is responsible for adding content to the sympathetic response and, as such, for regulating its propriety. The practices that the ideal spectator facilitates are crucial if the individual is to develop moral sensibilities which can then be used to inform their interaction with others. For, it is the ideal spectator who recreates the event in the observer's imagination as it is being played out in real time, but who does so substituting the observer for the observed such that the observer can find out how they would feel had they been in a directly analogous situation to that which the person principally concerned has just experienced (Smith, 1982 [1759]: I.i.1.4). In the absence of the human capacity to use the imagination to call forth the ideal spectator, no moral content can be imputed onto events. We can still rely upon our empirical spectator to witness events as before, but the empirical spectator has no direct moral role and, as such, can only guide a response that is marked by a detached, dispassionate indifference.

The constant interaction that the individual has with other people acts as an educative function for the imagination (Griswold, 1999: 128-9). It is through this that the individual learns how to pass moral judgement not only on other people but also on themselves. The first stage of this educative experience arises when moral sensibilities are stimulated by the individual's empirical spectator witnessing an event 
where the individual is neither the person principally concerned by the event nor the agent of it. In such circumstances, the ideal spectator recreates the event in the imagination in order to allow an emotive response to be projected towards the persons involved. A similar process occurs when the individual is one of those two persons, whereby the individual can learn more about how both their actions and their responses to other people's actions are received by others' sympathetic selves. The next stage requires the development of a suitably acute imagination, whereby the individual no longer needs to have physically witnessed an event for their moral sensibilities to be triggered. Instead of recreating an actual event as it is being played out in real time, an imagination of this nature can pre-emptively create the sense of an event in which the individual might choose to involve themselves. This then allows that individual vicarious insights via their ideal spectator into the likely response of other people should the imagined action subsequently be undertaken. Such a process entails the individual passing moral judgement on their own intended conduct. No other person is actually involved except in the individual's imagination. When the individual has harnessed this imaginative faculty so that it can become a consistent restraint on improper behaviour, the individual's ideal spectator has reached the stage that Smith called the impartial spectator (Smith, 1982 [1759]: III.1.2).

The impartial spectator is the means through which we can turn the capacity for sympathy back on ourselves in order to become the judge of our own intended conduct. The imagination provides the ability to perceive what we would think if we were to place ourselves vicariously in a directly analogous experience to that of somebody else, so it is but a short step to use the imagination to perceive what we would think of ourselves from that perspective (Fitzgibbons, 1995: 63). The most important aspect of the impartial spectator in this regard is that Smith ascribes to it a 
capacity that is denied the other senses. The individual's other senses are driven by passions which can often lead to the privileging of the self at the expense of other people. However, the individual's moral sense as embodied in the impartial spectator relegates the self to potential parity with other people and, as such, imposes restraint on the passions (Boyden Lamb, 1974: 675). It is necessary for the impartial spectator to be emotionally uninvolved at the moment of activation if it is to inspire the individual to produce the appropriate emotive response (Boltanski, 1999: 36). In this way, the impartial spectator acts as the individual's conscience (Smith, 1982 [1759]: III.2.3), manifesting itself in the individual's imagination as an advocate of conscionable behaviour.

It is exactly this sort of conscionable behaviour which is implored by fair trade campaigners and celebrated in so much of the academic literature on the subject. This suggests that there is scope for attempting to theorise the increasing popularity of fair trade consumption practices through the perspective of the Smithian impartial spectator. Yet, the precise framing mechanism which currently dominates discussion of the conscionable dimension of fair trade consumption is that of the satisfaction of justice for Third World producers. In order to see whether the Smithian framework still fits, then, it is therefore necessary to say a few words on Smith's concept of justice.

The first thing to note in this respect is that there can be no doubting the significance that Smith attaches to justice: it is nothing less than the existential condition for society (Smith, 1982 [1759]: II.ii.3.4). For social harmony to arise out of myriad interpersonal interactions, individual behaviour must be bound by an ethical code that provides clear prescriptions for the just treatment of others (Arrow, 1979: 158). This is the very minimum requirement. If a society is to flourish in any real 
sense it must be governed by both justice and virtue, but it can exist, albeit in a diminished state, without the latter (Khalil, 2000: 56). In the first instance, then, honing people's respect for justice is more important to Smith than developing their sensibilities towards acts of kindness.

From this relatively straightforward starting point, however, things begin to get more complicated. This is because, as Samuel Fleischacker notes (2004: 146), 'Smith appeals to justice in the course of many arguments, but he never explains what it is'. There are three separate sources of justice in Smith: natural liberty, moral sentiments and rights (ibid: 148-53). Yet, in all of these different treatments, he begins from pretty much the same premise. This is to assert, in the first instance, the moral primacy of the negative. That is, justice consists in the absence of harm (Morrow, 1989 [1929]: 166-7; Haakonssen, 1981: 85-9), thus entailing the outlawing of coercive demands made on an individual's person or property (West, 1976: 114; Campbell and Skinner, 1982: 172). Justice, then, primarily tells us what we are not to do in the interests of defending other people's autonomy, integrity and dignity (Song, 1997: 27).

The equivocation that subsequently follows depends on the degree to which Smith is willing to add positive duties to the negative duty of restraint from harming other people. In other words, he is inconsistent on whether justice requires anything other than judicious inaction such that harms are not enacted, or whether it requires that other people are entitled also to be provided with goods. His inconsistency on this question in turn depends upon the source from which the conception of justice originates. If that source is to be the political preference for a system of natural liberty, then no such positive duties are admissible in the definition of justice. Alternatively, if it is to be the contemporary stage of development of moral 
sensibilities, then the addition of positive duties is admissible up to the point at which they remain consistent with conditions of mutual sympathy. And if it is to be the claim to have a right satisfied, then again the addition of positive duties is admissible so long as the legitimacy of the right is generally agreed.

Smith's somewhat fuzzy conception of justice raises a number of important questions for those who would wish to view fair trade consumption practices through such a lens. Much would seem to turn on whether the consumer's choice to privilege the fair trade alternative can be linked to a notion of duty. If so, is this a positive duty, such that consumers can be legitimately expected to provide the good which is associated with that consumption choice? Or is it a negative duty, whereby any other consumption choice can be shown to impart harm on the producer for which the consumer is individually culpable? Of course, this all depends on what, exactly, is meant by justice. These are the questions that underpin the analysis in the following section.

\section{Fair Trade and the Attempted Inducement of Conscionable Consumption}

The primary goal of fair trade campaigners is to persuade consumers to use their purchases less as a means of signalling their own social status and more as a means of affirming the claims made on behalf of Third World producers for fair terms of exchange. In other words, fair trade campaigners attempt to change the symbolic properties of commodity consumption (Hughes, 2000: 176; Sayer, 2003: 350). Their aim is to challenge the conventional dynamics of commodity fetishism, which arise from the way in which consumption decisions are framed by calculations that 
privilege impersonal categories such as demand, supply and price (Harvey, 1990: 422-3; Hudson and Hudson, 2003: 417-9). In these circumstances, the consumer identifies solely with the physical and the economic characteristics of the product.

However, such characteristics have no independent moral status, so that the product itself can have no claim to ethical treatment. In order to validate ethical claims within the act of consumption, it is necessary for the consumer to be released from the cognitive constraints of the commodity fetish. If the campaign for fair trade is to be successful, it must change consumers' instinctive identification with the product in preference for a concern for the broader social relations of production. In effect, this is to uncover the producer who lies behind the product.

To phrase this in Smithian terms, the non-sentient characteristics of a product mean that it can never be the object of mutual sympathy. It simply makes no sense to suggest that a product can emit fellow-feeling for the person who purchases it and, as such, the commodity fetish denies the consumer the opportunity to project sympathetic concerns. The consumer's ideal spectator remains dormant in a relationship of this nature, because no act of the imagination can ever be sufficient to allow the consumer to understand what they might be feeling were they to find themselves in the social situation currently occupied by the product. The consumer can only activate this imaginative faculty when understanding themselves to be interacting, not with the product per se, but with the producer of that product. If a producer-oriented cognitive frame can be made to replace that of the conventional commodity fetish, then the consumer may well recognise the legitimate moral status of the producer and accept that the producer is consequently worthy of ethical treatment. 
One theme which is constantly replayed within the academic literature on fair trade is that of re-connection (e.g., Whatmore and Thorne, 1997: 297; Goodman, 2004: 891). The physical distance over which trade can now take place ensures that the consumer and the producer will almost always remain strangers to one another. The potential success of fair trade's challenge to conventional commodity fetishism hinges on the ability to subvert the anonymising effects that dominate the modern exchange economy. I leave for later the implications of the fact that such attempts to 're-personalise' the exchange relation do not entail the establishment of concrete social connections between the consumer and the producer. It is sufficient at this stage to note that what connection there is resides solely in the imagination of the consumer.

As Andrew Sayer (2003: 346) points out, mass produced commodities go from being indistinguishable in terms of their generic characteristics (I could choose one product amongst numerous identical alternatives) to something highly specific in the moment of purchase (this is the one that I have chosen). Fair trade's attempt to insert the image of the producer into the mind of the consumer is designed to qualify the generic indistinguishability of certain commodities by emphasising the particularities of the fair trade brand (Bryant and Goodman, 2004: 355). The strategy revolves, however, around a complex yet clearly asymmetrical connectivity between consumer and producer. At the economic level, this is a simple two-way commercial connection: the producer sells the product, the consumer buys it, and each is dependent on the other if the exchange is to go ahead. Yet, the transaction itself is predicated upon the prior establishment of a one-way psychological connection which exists solely in the mind of the consumer and which tells the consumer that it is the right thing to do to prioritise the fair trade product. Nonetheless, if we are to follow 
Smith on the derivation of moral sensibilities, for such thoughts to be in the mind of the consumer in the first place means that the consumer must have been able to imaginatively reconstruct the feelings of their vicarious self when faced with the same circumstances as those confronting Third World producers. This, in turn, is not an imaginative leap that the individual is capable of making on their own. To do so requires that they have knowledge, elicited from direct observation, of the circumstances that their imagination is trying to replicate or, failing that, some substitute for actual knowledge that is produced by a convincing narrative.

It is primarily at the narrative level that fair trade campaigners focus their interventions into the politics of consumption. A visit to the websites of most fair trade organisations allows the First World consumer to 'meet' a representative Third World producer, where simply clicking on their picture enables the consumer to learn more about them and offers a glimpse of their world (e.g., fairtrade.org.uk; maketradefair.com; oxfam.org/fairtrade). Such images are usually accompanied by testimonials which allow producers to say in their own words how they are helped by consumers consciously incorporating themselves into fair trade networks (Goodman, 2004: 900). These simple storytelling devices are designed to de-anonymise the act of consumption, if only through the creation of vicarious sentimental attachments. They focus on revealing aspects of the life history of a producer who stands to benefit from the adoption of the behavioural norms associated with fair trade. Initially, this is about putting a face and a name to the process of international trade. The next step is then to trust the consumer's imagination to be able to proceed from having 'met' one Third World producer to being able to envision many such producers who might share similar characteristics, and from there to being able to understand how they would 
feel and what their hopes would be were they to live any one of those producers' lives.

As Michael Goodman (2004: 898) suggests, there are two distinct moments of commodification involved in bringing the fair trade product to market: one relating to the physical act of making the product and the other relating to what he calls ‘discursive/semiotic production’. The two are inextricably linked. The first moment is what makes a fair trade product a product, whilst the second is what makes it specifically a fair trade product. This second moment is visible in the Fair Trade label that all officially accredited products carry (Renard, 2003: 94), and it is also manifested in the politically-loaded description of the product's social relations of production which normally appears on its packaging (Hughes, 2000: 179). Goodman (2004: 893) goes as far as to argue that the very reason for the consumer to buy the fair trade product is 'written on the commodities trafficked from one part of the globe to another, connecting these places in a novel economy of semiology. In other words, the commoditization of fair trade facilitates a material and discursive 'scale jump' that, in effect, stitches consumers to the very places and livelihood struggles of production'.

This is a bold claim, and it is almost certainly to overstate the point. But, if true, it speaks of consumers who, in a Smithian sense, have no need to rely on their empirical spectator to act as the basis for forming moral judgements. For, their ideal spectator must be in such perfect sympathetic accord with the likely sentiments of the Third World producer that they have been able to activate a genuinely functioning impartial spectator. But, even accepting for a moment that such claims are well founded, to what moral end might the consciousness arising from the activation of an impartial spectator be put? 
The practice of purchasing fair trade products is typically viewed as dignifying conduct, whereby, despite their different lifestyles, the consumer is able to display solidarity with the producer by supporting producers' attempts to earn themselves a more comfortable material existence (Renard, 2003: 95). The concrete economic relationship linking producer and consumer therefore becomes a means of conferring upon the purely vicarious social relationship that exists between them the same moral status as would be appropriate were that relationship much more intimate. Were it to take a concrete form then there is good reason to presume that it would be a relationship of justice. Perhaps as a consequence of this, the vicarious relationships of fair trade also tend to be treated in the literature on the subject as ones of justice. However, the precise concept of justice in operation there is even more fuzzy than Smith's. It is possible, though, to read the intimations of justice in the literature on fair trade as an unspecified synthesis of the three sources of justice identified in Smith by Fleischacker.

First, there is the notion of justice which appears in the lectures that Smith delivered before the publication of the first edition of The Theory of Moral Sentiments. This is the natural liberty interpretation (Fleischacker, 2004: 148-9). Applied specifically to commercial transactions, it states that justice requires the defence of a system of free exchange between consenting parties. For free exchange to take place, the terms of the exchange are struck on the basis of the intrinsic value of the product - what Smith (1981 [1776]: I.vii.5) calls its natural price - rather than the distribution of social power amongst the parties to the exchange. Under the justice criterion of natural liberty, then, free exchange is fair exchange by definition (Peil, 1999: 82-3). Such a theme arises in the contemporary literature on fair trade through 
reference to the frustrated pursuit of Smith's natural prices in the heavily-protected markets for Third World agricultural products.

Fair trade campaigners accuse the World Trade Organization of presiding over a system of agricultural subsidies which allows First World governments to skew the terms of international trade in favour of their own producers. These subsidies artificially lower the price at which First World producers can sell their agricultural products, thus nullifying the comparative advantage of Third World producers and forcing them to lower their prices if they are to be able to sell their goods (Renard, 2003: 89). Moreover, this situation is compounded by the fact that monopsonistic First World distributors are able to structure the terms of the exchange to their own ends (Whatmore and Thorne, 1997: 297). This applies a further squeeze on the product price which is completely unrelated to its intrinsic value. Third World producers are hence denied justice in the act of commercial exchange due to what the literature depicts as the illegitimate distortion of natural prices. From this perspective, fair trade consumption practices constitute acts of justice insofar as they circumvent pricing dynamics that impede the conditions of fair exchange.

Second, there is the notion of justice which Smith develops in The Theory of Moral Sentiments and which represents his first attempts to add positive virtues to the natural liberty interpretation of justice. This is a notion of justice which is grounded in the development of individuals' moral sensibilities (Fleischacker, 2004: 149-52). Such a theme arises in the contemporary literature on fair trade when the focus is less on the injustices that are enacted on producers by the commercial structure of world trade and more on the potential for consumers to do good. The presence of reflexive consumers is pretty much taken as given in this perspective. They are understood to be expressing their preferences for treating distant strangers justly through the 
purchases that they make (Shaw and Shiu, 2002: 286). It is thus suggested that the practice of fair trade consumption entails consumers knowingly affirming the principles of distributive justice (Goodman, 2004: 892). Their willingness to pay a price which at the very least is consistent with the product's intrinsic value provides a means of negating the regressive distributional implications of the absence of free exchange within the system of commercially managed world trade. The affirmation of the notion of a fair price serves as some sort of corrective to current distributive injustices.

Third, there is the notion of justice which appears in Smith's Lectures on Jurisprudence and which represents his most detailed attempt to establish a theory of positive duties on the basis of formal obligations. This is a notion of justice which is grounded in the acknowledgement that other people have rights and that these rights are not contingent on the rights-holder possessing particular social characteristics (Fleischacker, 2004: 153). Such a theme arises in the contemporary literature on fair trade in the discussion of the moral arbitrariness of birthplace. Rights are argued to apply irrespective of geographical fortune (Smith, D., 1998: 32), which immediately nullifies whatever significance might otherwise be read into the fact that producers and consumers in fair trade relationships share exceedingly few social characteristics. Producers in such relationships do not need to demonstrate that they have the same community allegiance as consumers in order to prove that they have the right to just treatment. Instead, all that is required is for First World consumers to act on the recognition: i) that Third World producers have the same existential needs as they do and; ii) that they have a responsibility to ensure that those needs are not left unmet. Ethical obligation has been shown to act as a constitutive element of intention for the vast majority of fair trade consumers (Shaw and Shiu, 2002: 291-2). At least in their 
own minds, then, such consumers would seem to experience some sense of compulsion to conduct themselves on the basis of legitimate rights-based claims that producers have to be treated justly.

The question that needs to be answered in the following section is whether the above intimations of Smithian justice which can be identified in the literature on fair trade add up to anything more substantial than that. In other words, are these similarities merely coincidental, or is it possible to construct a genuinely grounded explanation of fair trade consumption on the basis of Smith's theory of justice? Two issues will guide my analysis. The first will be Smith’s discussion of the influence of distance-decay dynamics on the activation of moral sensibilities, and the second will be the important distinction that he draws between justice and beneficence.

\section{Justice, Beneficence and Distance-Decay Dynamics in Fair Trade Consumption}

The success of fair trade as a development strategy revolves around the continuing incorporation of ever more First World consumers into its economic networks. In turn, this is likely to depend upon whether or not there are implicit spatial boundaries across which it becomes ever more difficult to develop moral sensibilities that are consistent with the instinctive recognition of abstract justice claims. Smith's friend and most important intellectual influence, David Hume, certainly believed that this was the case. He argued (Hume 1988 [1740]: 427-32) that such sensibilities are naturally stronger the greater the social connection between the two people involved. Thinking merely of the example of strangers, Hume's position was that the ability to recognise the moral worth of a stranger will necessarily be more finely honed between 
two unrelated members of the same community than between two unrelated people who are socially as well as spatially distant from one another.

Perhaps surprisingly given the significance of such a suggestion, the existing academic literature on fair trade tends not to dwell on this question. Reference is frequently made to a novel economic geography of ethical consumption, where its novelty derives from the fact that it is constituted by interpersonal relationships which form on the same moral basis irrespective of the spatial coordinates of the people involved. Fair trade is assumed to operate in the 'interstices of globalization' (Renard, 1999: 484), such that: i) the global becomes the local in the minds of the participants (Raynolds, 2002: 410); ii) a genuinely transnational economic realm is created (Crang, Dwyer and Jackson, 2003: 438); and iii) the spatial temporalities that give rise to distance-decay dynamics are dissolved (Harvey, 1990: 423). Much has consequently been written - and usually uncritically at that - about fair trade's ‘expansive spatial dynamics of concern’ (Goodman, 2004: 891).

Invoking Smith's explanation of the development of moral dispositions, though, this might well be to run ahead of the argument. Smith confronts Hume's distance-decay problem with a detailed exposition which he begins by contrasting the most intimate emotions with those that are less acute. He argues that an emotion is much more straightforward to communicate in simple language if it is somewhat banal than if it is particularly exacting on the moral sensibilities (Smith, 1982 [1759]: I.ii.1.8). Yet, this does not mean that we do not desire to show that our moral sensibilities are in accord with those of other people for even the most intimate emotive experience. We still hope to issue the appropriate form and degree of sympathy when witnessing other people experience circumstances that elicit an emotive response from them, and we still hope to receive the appropriate form and 
degree of sympathy when these spectatorial roles are reversed. This applies even when those emotions are difficult to put into words. However, at this point, sympathy can only arise from the physical act of witnessing an event, which has to be relied upon to make good the lack of direct communication about how the event has impacted upon the person most immediately involved. If we are to decide whether or not fair trade embodies a novel economic geography in which distance-decay dynamics have no role in the development of moral sensibilities, then much depends on how literally we insist on understanding the word 'witness'.

Smith appears to suggest (1982 [1759]: VII.ii.4.14) that observation is a more powerful socialising stimulant than communication in eliciting a sympathetic response. But fair trade replaces observation of the event (how many First World consumers have directly seen the livelihood struggles of Third World producers?) with communication about it (i.e., the potted life histories of those producers that form part of the packaging of their products). Can the intimacy of those livelihood struggles therefore genuinely be transmitted into the imaginative faculties of First World consumers? The answer to this question would seem to reduce to whether or not an individual needs to be physically present to see an event if that event is to be imbued with genuine moral significance for them. Yet, on this issue Smith has been read in two mutually incompatible ways within the secondary literature.

Smith takes it as given (1981 [1776]: IV.ii.10) that all individuals have superior knowledge of what he calls their 'local situations' and that they consequently find it easier to produce sympathetic emotions which are commensurable with such situations. His theory of the knowledge on which moral dispositions are based is therefore consistent with his theory of knowledge as a whole. In the latter, he continually emphasises the significance of familiarity. According to Smith, 
knowledge has calming psychological consequences for the person in possession of it, because the mind's ability to understand the unknown relies on being able to relate that unknown to familiar things that are already known. It is only in such circumstances, he says (1982 [1795]: II.12), that knowledge can allay the 'tumult of the imagination'. The human mind, in other words, has a propensity for wanting to see connections between appearances in the real world (Skinner, 1979: 18). Thus, there is an obvious observational dimension in Smith's theory of knowledge formation.

Given this, it is relatively straightforward to understand why some authors have suggested that Smithian spectatorial sympathy requires direct sight of the circumstances which trigger the moral sensibilities to elicit an emotive response. David Marshall (1984: 596) writes of the 'epistemological distance' that must always exist between observer and observed and that prevents the observer from genuinely sharing the sentiments of the observed rather than merely reconstructing them. In such settings, verisimilitude of sentiments can only arise if the former keeps the latter physically in sight at all times. Self-approbation and disapprobation are instances of reflected sympathy (Morrow, 1989 [1928]: 175-6), but one presumably needs to see something if one is to be influenced by its reflection. Fonna Forman-Barzilai has arguably made this point most forcefully. She focuses (2005: 190) on what she takes to be the irreducible partiality embedded in the sympathy principle: 'physical proximity begets familiarity, which in turn makes affection stronger, understanding more accurate, sympathy likelier, and other-concern more natural and appropriate' (see also Levy, 1995: 302). Such partiality results from the fact that moral sensibilities derive the greatest depth of meaning in face-to-face encounters regulated 
by sight - what Forman-Barzilai (2005: 189) describes as 'sentimental nearsightedness'.

Others, however, have chosen to interpret Smith’s thoughts on distance-decay dynamics rather differently. From this perspective, familiarity might be understood in psychological terms, rather than as an aspect of physical proximity, which means that there may be no need to think of a one-to-one correspondence between feeling morally implicated in an event and being spatially close to its occurrence (Hollander, 1987: 313; Weinstein, 2006: 2). As Boltanski notes (1999: 36-7), Smith uses two different terms - 'spectator' and 'bystander' - through which we come to reflect the emotions that our moral sensibilities trigger back into our own person. Unfortunately, he provides no definition which would allow us to distinguish what he means by the two. Nonetheless, as 'bystander' implies a person who is in the right place at the right time to physically watch an event unfold, Smith's use of another word to describe different circumstances appears to infer that a 'spectator' embodies other characteristics. One might understand Smith's notion of spectator in generic terms, as the means through which one becomes aware of the significance of an event, irrespective of whether that awareness emerges from direct observation or is created vicariously through acts of the imagination. Boltanski concludes (1999: 37) that 'Smith did not seek to emphasise the tension between a necessarily local face to face encounter ... and the conveyance over distance of a representation of suffering'.

Andrew Skinner makes much the same point when he suggests (1979: 55) that Smith was sufficiently pragmatic to admit that no act of the imagination could ever be enough to render the person not principally concerned fully conversant with every detail of an event. Yet, for Smith, this does not prevent some aspects of that event from entering the consciousness of people who were not present as it occurred, and 
this may be all the information that is required - however it is come by - to facilitate an informed value judgement. The spatial coordinates of the spectator might therefore influence the precise manner in which moral sensibilities are activated, but they do not necessarily alter the probability that they will be activated. Smith himself, of course, stated quite categorically (1982 [1759]: IV.2.6) that 'we are capable of discerning the remote consequences of all our actions'.

It is possible to follow the secondary literature, then, to read back into Smith's work two entirely antithetical positions on the question of whether physical distance presents a notable obstacle to the expression of sympathetic sentiments. Whichever position we choose to adopt, though, one thing seems sure, as it is challenged by neither camp. This is the suggestion that Smith works to a model of moral sentiments which revolves around what Russell Nieli calls (1986: 620) competing 'spheres of human intimacy’. Smith assumes as an empirical fact (1982 [1759]: VI.ii.2.1) that there is a hierarchical 'order in which individuals are recommended to our [moral sensibilities]'. According to Smith, the most compelling sphere of human intimacy for any person is the individual him or herself. From there, we move outwards to ever expanding but ever weakening spheres of intimacy in which it is possible for us to be socialised into activating our moral sensibilities, but we do so with an increasing lack of priority and urgency. These widening spheres of intimacy beyond the self consist of, respectively, the near family, the extended family, friends, occupational colleagues, neighbours and, finally, fellow nationals (Nieli, 1986: 620-2). This is where Smith stops, leading Forman-Barzilai to conclude (2005: 205) that it is impossible to constitute a cosmopolitan world on the basis of Smith's moral theory.

If true, then this would seem to have important implications for understanding fair trade consumption practices from a Smithian perspective. It is clear that fair trade 
campaigners work specifically on raising awareness of the livelihood struggles of Third World producers amongst potential consumers of their products, in a manner that is consistent with attempts to activate a Smithian impartial spectator. Yet, if we are to read Smith literally on the outer limits of the spheres of human intimacy, then all this effort might be in vain. People could well still choose to engage actively with fair trade consumption practices, but it will be for reasons other than the display of Smithian sympathy. In order to revive such an explanation for purchasing fair trade products, it is necessary to show how consumers might establish an additional sphere of human intimacy, one that extends beyond fellow nationals to incorporate distant strangers of other nationalities. However, if spectatorial activities require the person principally concerned to be kept physically in sight at all times, then this is unlikely to be possible. Third World producers can only be incorporated into the spheres of human intimacy of First World consumers if spectatorial activities can be undertaken on a purely vicarious basis.

It is worthwhile at this stage of the discussion to revisit the distinction that Boltanski draws (1999: 40-1) between the two types of spectator to be found in Smith's moral theory: the empirical and the ideal spectator. In previous paragraphs I reviewed the incommensurable interpretations from the secondary literature of Smith's position on distance-decay dynamics. In turn, these are grounded in different emphases on Boltanski's two spectatorial moments. For those who pay particular attention to the activities of the empirical spectator, distance-decay dynamics provide a potentially insuperable impediment to the derivation of genuine moral sympathy. This is for the simple reason that the empirical spectator is not privy (in the literal physical sense) to the circumstances which trigger an emotive response in distant strangers. By contrast, for those who pay particular attention to the ideal spectator, 
distance-decay dynamics appear less problematic. So long as the individual is presented with sufficient information on given circumstances to generate an informed value judgement about them, the imaginative faculties of the ideal spectator can circumvent the need for physical observation and the activation of moral sensibilities can proceed on that basis. The key to constituting ethical consumers via fair trade, then, would appear to reside in the realm of the ideal spectator rather than that of the empirical spectator.

For Smith (1982 [1759]: VI.ii.1.1), the activities of the empirical and the ideal spectators are equivalent to the difference between 'the substance' and 'the shadow', insofar as directly observed social situations are always likely to impose greater clarity on the sympathetic response than are situations that are reconstructed solely in the imagination (Levy, 1995: 299-300). Yet, this does not mean that we cannot sympathise with situations that are beyond our immediate experience. Indeed, Smith goes to some length (1982 [1759]: I.i.1.12-13) to describe situations that we can either never have been in or can never be in again to demonstrate that sympathy does not rely on experience. In such circumstances, direct observation must necessarily cede precedence to acts of the imagination if moral sensibilities are to be activated (Rizvi, 2002: 248-9).

Within Smith’s moral system, then, the imagination is able at times to override the lessons learned from experience to link immediate sentiment with distant consequence. Moreover, such links are far from accidental (Khalil, 2000: 50), as the decision-maker is able to derive a sense of what will happen beyond his or her most obvious sphere of action. It is only necessary for individuals to gain the perception that their actions will do good for those actions to appear morally worthwhile in their own eyes. Any person who stands to benefit if that perception is acted upon therefore 
becomes the potential subject of preferential treatment (Nieli, 1986: 624). This applies irrespective of whether the likely beneficiary is conscious of being in such a position and irrespective of whether the decision-maker has any plausible claim to genuinely know the likely beneficiary. When Smithian sympathy exists solely on the basis of imaginative acts, it must necessarily stop short of the total identification of one person with another (Marshall, 1984: 600-1). But this does not prevent the exercise of sympathy per se.

All of this appears to be good news in the attempt to construct a moral basis for fair trade consumption practices from Smith's moral theory. Distance-decay dynamics do not appear to be necessarily insurmountable, as the First World consumer of fair trade products might still be able to construct a sense of moral duty towards the Third World producers of those products even if they do not share an obvious sphere of human intimacy. After all, Smith was clear (1982 [1759]: VI.ii.1.2) that all individuals owe special duties to 'the poor' who, on account of their poverty alone, represent 'the greatly unfortunate' within society. He assumed that this condition of great misfortune subverted the hierarchical order of considerations to be found in his ever expanding spheres of human intimacy. Moreover, it was of no great importance to him that the sympathy exercised on behalf of the poor was in almost all instances purely an imaginative act. From this perspective, it appears perfectly feasible to suggest that the decision to become a fair trade consumer arises from an imaginative act designed to express moral sympathy with the everyday situation faced by Third World producers. The only thing that now remains to be done is to comment on the moral content of the sympathy thus produced.

To do this, it is necessary to draw upon the important distinction that Smith posits between justice and beneficence. According to Smith, compassion for the poor 
is indicative of virtuous behaviour, but the virtue in question originates in our benevolent passions (Young and Gordon, 1996: 7). This is a category of virtue whose display is both voluntary and discretionary (Smith, 1982 [1759]: II.ii.1.7). Human life is conducted within societies that are necessarily less than whole in the absence of benevolent virtues, but it still remains possible in such circumstances. As Smith puts it (ibid: II.ii.1.3), 'the mere want of beneficence tends to do no real positive evil'. We are thus encouraged to distinguish between situations in which a genuine harm has been perpetrated and situations which are characterised by a mere absence of good. For Smith, the former correspond to contexts in which the appropriate sympathetic response is one conditioned by sentiments of justice, whereas the latter correspond to contexts in which the appropriate sympathetic response is one conditioned by sentiments of beneficence. Both types of sympathy carry intentionality with them - in Weinstein's words (2006: 16), 'it is aimed at something' - but the motivation for exercising the sympathy differs across cases (Khalil, 1998: 216-7). Beneficence originates in an abstract commitment to 'something better', and this commitment in turn is formed purely as an imaginative act. By contrast, justice originates in regulated rule-following which prevents one individual from exercising coercion over another.

The question thus becomes whether fair trade consumption practices are a reaction to a positive harm or a reaction to an absence of good. Four points can usefully be made in this respect. First, Smith suggests that spectatorial responses are likely to be more precise, more exacting and more consistently applied when they are directed at a perceived harm than when they are directed at a perceived absence of good (Fleischacker, 2004: 156-7). The disparities in the take-up rate of fair trade consumption practices consequently suggest that they are a reaction to an absence of 
good. Second, fair trade consumption practices involve a purely voluntary decision of whether to purchase one product as opposed to another. The presence of harm tends to elicit responses that do away with voluntary gestures and are based on compulsion. Once again, we would not appear to be talking about responses to the presence of harm in this instance. Third, fair trade consumption practices remain resolutely wedded to a world of market exchanges. In such a world, rule-following behaviour is typically restricted to the conduct of the exchange itself, and all sense of broader social harm dissipates so long as the exchange takes place in a non-coercive environment. Fourth, Smith links the presence of harm to threats to social order (Skinner, 1979: 61). As no connection has yet been made between fair trade and the maintenance of world order, it is difficult to imagine that fair trade consumption practices do more than correct a perceived absence of good.

Whilst all of these points hint very strongly that fair trade consumption practices belong to Smith’s category of beneficence rather than justice, this argument can be made even more forcefully by studying the manner by which Smith believes we come to exhibit the sentiments of justice. His somewhat minimalist conception of justice treats it, in the first instance, as the most basic requirement of social living that individuals must internalise if they are to live within a functional society. As such, the principles of justice are an embodiment of the interpersonal norms within a given society which guide one individual's behaviour with respect to another. For this reason, Smith's starting point is commutative justice (where obligations are concentrated in the relationship between individuals) rather than distributive justice (where obligations run from society as a whole to the individual) (Young and Gordon, 1996: 2-3). At first glance, fair trade consumption practices might appear to fit this notion of justice, because they clearly involve relationships between individuals. But 
to what extent is anyone truly obligated to purchase a fair trade product rather than one that lacks such accreditation? For, no formal sanction can be imposed upon an individual who chooses not to purchase the fair trade alternative. In this respect, there is an important difference between commutative justice which can be enforced by societal regulation of interpersonal norms and distributive justice which belongs in the sphere of private virtue (Verburg, 2000: 23). Indeed, one might be tempted to go as far as to suggest that, for Smith, conduct consistent with the principles of distributive justice is actually less to do with justice than it is with beneficence.

This is because Smithian justice requires more than an independent sympathetic action that an individual can undertake in isolation from other people. It requires a situation of mutual sympathy, whereby justice resides in the simultaneous recognition between observer and observed that both responded in an appropriate fashion given the situation in which they found themselves. Smithian justice therefore entails both the person principally concerned by a set of circumstances and the person responding to placing their vicarious self in a similar context to experience exactly the same sentiments. From this perspective, a just relationship involves two things: i) each party being able to activate their ideal spectator to experience a simulated reconstruction of the emotions that the other person is likely to be experiencing; and ii) each party judging those emotions to be appropriate to the situation that triggered them.

However, this is the sort of mutual imaginative reconstruction that the practice of fair trade does not allow. There is an important asymmetry in the structure of fair trade. Despite the best efforts of fair trade campaigners to de-anonymise the trading relationship, this has been a decidedly one-way process which works only to the benefit of the consumer. First World consumers are provided with information about 
the type of Third World producer with whom they are trading. This enables them to reconstruct the context of Third World livelihood struggles in their own minds and, as such, to confer sympathy on the emotions that they presume the producers will feel. But this same sort of imaginative projection into another person's life context is not also conferred upon the producers. They will be aware that their products are being sold, and they will also be aware when their products are sold with official fair trade accreditation, but they will not know which consumers they are trading with. The packaging of fair trade products enables First World consumers to gain some sense of who the Third World producers are, but the practice of fair trade lacks the reciprocal dimension which would also allow the reverse to apply. The producers can only endorse the structure of fair trade in which they are incorporated, rather than the actions of the consumers who buy their products. Of course, no trading structure can emit fellow-feeling for the producers who are incorporated into it, so the producers of fair trade products are denied the opportunity to engage sympathetically through the act of commercial exchange. Situations of mutual sympathy between consumer and producer are therefore impossible within contemporary fair trade networks and, as such, so too are situations of Smithian justice. It is thus necessary to conclude, at least from a Smithian perspective, that fair trade consumption practices are acts of beneficence and not acts of justice.

\section{Conclusion}

It may come as something of a surprise that the foregoing analysis has led to the conclusion that the virtue encapsulated in fair trade consumption decisions has little, 
and possibly even nothing, to do with justice. Most fair trade consumers are unlikely to have read the academic literature on the subject, which typically posits just behaviour as the moral basis of the decision to engage actively with fair trade consumption practices. But they are likely to be familiar with the arguments of fair trade campaigners, including the product endorsements that appear on the goods they buy, and these also play upon the same theme. They emphasise that the decision to purchase the product is not an act of charity (which might be seen in some way to disparage the hard-working and commercially proficient producers) so much as an act of justice (thereby recognising producers' industriousness and dignifying their livelihood struggles). However, as I hope to have demonstrated through the preceding analysis, this is not an image that can be sustained by reconstructing the moral basis of fair trade consumption practices via Smith's account of the development of moral sensibilities. Such consumption is certainly virtuous, but from a Smithian perspective the virtue in question is not justice but beneficence.

Three responses are possible to such a finding. The first response is to suggest that it does not necessarily matter that fair trade consumption practices cannot be explained as an act of justice from a Smithian perspective, because it can be explained in that manner from other philosophical starting points. I would appeal to my fellow IPE scholars working on issues of trade justice to show the way in this respect. The second response is to suggest that it might not necessarily matter at all what a Smithian perspective says on fair trade consumption practices, because what counts is what the consumers themselves believe. If First World consumers continue to be socialised into thinking that their actions affirm legitimate justice claims made on behalf of Third World producers, then this is likely to be of greater practical consequence than any philosophically based discussion. The third response, however, 
is to take the Smithian perspective seriously and to unpack its implications for the way in which the dynamics of trade justice are understood in IPE.

From a Smithian perspective, the decision to purchase a fair trade product corresponds much more closely to an attempt to counteract the absence of a good in the life conditions of Third World populations as a whole rather than to avoid an individually-perpetrated harm on a specific Third World producer. According to Smith, it is only by neutralising a particular harm that an individual is genuinely acting justly. If a consumer chooses not to purchase a fair trade product then it would be difficult to say that this individual has knowingly and deliberately enacted an explicit harm on a particular producer. It might still be possible to say that Third World producers experience harm in such circumstances, but the harm is the result of the current asymmetries of the international trading system and not the result of the inaction of an individual consumer. This, then, appears to link issues of trade justice to the current asymmetries of the international trading system.

This might be a somewhat unsettling finding for advocates of a more critical IPE which seeks to prioritise the study of individuals in action over the study of formal policy-making institutions (e.g., Watson, 2005: 38-9). For, it suggests that, in order to study the dynamics of trade justice, one should be interested primarily, and perhaps even solely, in the structure, content and outcomes of negotiations at the World Trade Organization. It is within these negotiations that the asymmetries of the existing system will either be reproduced or overwritten with new rules that are more conducive to the fair treatment of Third World producers. It is also here, then, that the current pattern of harms arising from the system of international trade will either be affirmed or challenged. As such, from the perspective outlined above, the World Trade Organization seems to be the guardian of trade justice, rather than the actions of 
individual consumers. This consequently appears to situate issues of trade justice within the remit of what Craig Murphy and Roger Tooze (1991) have aptly described as 'orthodox IPE'.

There is surely an irony in this conclusion. The priority which Smith gives to individual motivation in his explanation of moral being suggests an emphasis on the study of individuals in action. Yet, the logic of the Smithian perspective outlined above links individual fair trade consumption choices to the private virtue of beneficence and matters of trade justice to the structures of the international trade system. As such, it abstracts the study of individuals in action from discussions of trade justice, and it focuses those discussions instead on the study of formal policymaking institutions.

Notes

Whilst absolving them from any responsibility, I would like to thank two of the EJIR's anonymous reviewers for their many immensely insightful and helpful comments on an earlier draft of this article. I would also like to express my gratitude to three of my PhD students - Paul Lewis, Simon Glaze and Urszula Bodzek - for our ongoing discussions on the content and the nature of Smith’s work.

\section{References}

Arrow, Kenneth (1979) 'The Division of Labor in the Economy, the Polity, and Society', in Gerald O’Driscoll (ed) Adam Smith and Modern Political Economy: 
Bicentennial Essays on The Wealth of Nations, pp. 153-164. Ames, IA: Iowa State University Press.

Berry, Christopher (2004) 'Smith Under Strain', European Journal of Political Theory 3 (4): 455-464.

Boltanski, Luc (1999) Distant Suffering: Morality, Media and Politics, translated by Graham Burchell. Cambridge: Cambridge University Press.

Boyden Lamb, Robert (1974) ‘Adam Smith’s System: Sympathy not Self-Interest’, Journal of the History of Ideas 35 (4): 671-682.

Bridel, Pascal and Christophe Salvat (2004) 'Reason and Sentiments: Review of Emma Rothschild's Economic Sentiments: Adam Smith, Condorcet and the Enlightenment', European Journal of the History of Economic Thought 11 (1): 131-145.

Bryant, Raymond and Michael Goodman (2004) 'Consuming Narratives: The Political Ecology of 'Alternative' Consumption', Transactions of the Institute of British Geographers 29 (3): 344-66.

Campbell, Roy Hutcheson and Andrew Skinner (1982) Adam Smith. London: Croom Helm.

Crang, Philip, Claire Dwyer and Peter Jackson (2003) 'Transnationalism and the Spaces of Commodity Culture', Progress in Human Geography 27 (4): 438-456. Fleischacker, Samuel (2004) On Adam Smith's Wealth of Nations: A Philosophical Companion. Princeton, NJ: Princeton University Press.

Fitzgibbons, Athol (1995) Adam Smith's System of Liberty, Wealth, and Virtue: The Moral and Political Foundations of The Wealth of Nations. Oxford: Clarendon Press. 
Forman-Barzilai, Fonna (2005) 'Sympathy in Space(s): Adam Smith on Proximity', Political Theory 33 (2): 189-217.

Fusfeld, Daniel (2002) The Age of the Economist, ninth edition. London: Addison Wesley.

Goodman, Michael (2004) 'Reading Fair Trade: Political Ecological Imaginary and the Moral Economy of Fair Trade Foods’, Political Geography 23 (7): 891-915.

Griswold, Charles (1999) Adam Smith and the Virtues of Enlightenment. Cambridge: Cambridge University Press.

Haakonssen, Knud (1981) The Science of a Legislator: The Natural Jurisprudence of David Hume and Adam Smith. Cambridge: Cambridge University Press.

Harvey, David (1990) 'Between Space and Time: Reflections on the Geographical Imagination', Annals of the Association of American Geographers 80 (3): 418434.

Hollander, Samuel (1987) Classical Economics. Oxford: Basil Blackwell.

Hudson, Ian and Mark Hudson (2003) 'Removing the Veil? Commodity Fetishism, Fair Trade, and the Environment', Organization and Environment 16 (4): 413430.

Hughes, Alexandra (2000) 'Retailers, Knowledges and Changing Commodity Networks: The Case of the Cut Flower Trade', Geoforum 31 (2): 175-90.

Hume, David (1988 [1740]) A Treatise of Human Nature, second edition with text revised and notes by P.H. Nidditch. Oxford: Oxford University Press.

Khalil, Elias (1998) 'Is Justice the Primary Feature of the State? Adam Smith's Critique of Social Contract Theory', European Journal of Law and Economics 6 (3): 215-230. 
Khalil, Elias (2000) ‘Making Sense of Adam Smith’s Invisible Hand: Beyond Pareto Optimality and Unintended Consequences', Journal of the History of Economic Thought 22 (1): 49-63.

Levy, David (1995) 'The Partial Spectator in the Wealth of Nations: A Robust Utilitarianism', European Journal of the History of Economic Thought 2 (2): 299-326.

Marshall, David (1984) 'Adam Smith and the Theatricality of Moral Sentiments', Critical Inquiry 10 (4): 592-613.

Mitchell, Harvey (1987) ““The Mysterious Veil of Self-Delusion” in Adam Smith’s Theory of Moral Sentiments’, Eighteenth-Century Studies 20 (4): 405-421.

Montes, Leonidas (2004) Adam Smith in Context: A Critical Reassessment of Some Central Components of his Thought. Basingstoke: Palgrave Macmillan.

Morrow, Glenn (1989 [1928]) 'Adam Smith: Moralist and Philosopher', in John Maurice Clark et al Adam Smith, 1776-1926: Lectures to Commemorate the Sesquicentennial of the Publication of The Wealth of Nations, pp. 156-179. Fairfield, NJ: Augustus M. Kelley Publishers.

Murphy, Craig and Roger Tooze (1991) 'Getting Beyond the 'Common Sense’ of the IPE Orthodoxy', in idem (eds) The New International Political Economy, pp. 11-31. Boulder, CO: Lynne Rienner Publishers.

Nieli, Russell (1986) 'Spheres of Intimacy and the Adam Smith Problem', Journal of the History of Ideas 47 (4): 611-624.

Peil, Jan (1999) Adam Smith and Economic Science: A Methodological Reinterpretation. Cheltenham: Edward Elgar.

Raynolds, Laura (2002) 'Consumer/Producer Links in Fair Trade Coffee Networks', Sociologica Ruralis 42 (4): 404-424. 
Renard, Marie-Christine (1999) 'The Interstices of Globalization: The Example of Fair Trade Coffee’, Sociologicus Ruralis 39 (4): 484-500.

Renard, Marie-Christine (2003) 'Fair Trade: Quality, Markets and Conventions', Journal of Rural Studies 19 (1): 87-96.

Rizvi, S. Abu Turab (2002) ‘Adam Smith’s Sympathy: Towards a Normative Economics', in Edward Fullbrook (ed) Intersubjectivity in Economics: Agents and Structures, pp. 241-253. London: Routledge.

Sayer, Andrew (2003) '(De)Commodification, Consumer Culture, and Moral Economy’, Environment and Planning D: Society and Space 21 (3): 341-57.

Shaw, Deidre and Edward Shiu (2002) 'An Assessment of Ethical Obligation and Self-Identity in Ethical Consumer Decision-Making: A Structural Equation Modelling Approach', International Journal of Consumer Studies 26 (4): 28693.

Skinner, Andrew (1979) A System of Social Science: Papers Relating to Adam Smith. Oxford: Clarendon Press.

Smith, Adam (1981 [1776]) An Inquiry into the Nature and Causes of the Wealth of Nations, Volume One, The Glasgow Edition of the Works and Correspondence of Adam Smith, edited by R.H. Campbell and A.S. Skinner. Indianapolis, IN: Liberty Fund.

Smith, Adam (1982 [1759]) The Theory of Moral Sentiments, The Glasgow Edition of the Works and Correspondence of Adam Smith, edited by D.D. Raphael and A.L. Macfie from the seventh edition of the original. Indianapolis, IN: Liberty Fund. 
Smith, Adam (1982 [1795]) Essays on Philosophical Subjects, The Glasgow Edition of the Works and Correspondence of Adam Smith, edited by W.P.D. Wightman. Indianapolis, IN: Liberty Fund.

Smith, David (1998) 'How Far Should we Care? On the Spatial Scope of Beneficence’, Progress in Human Geography 22 (1): 15-38.

Song, Hyun-Ho (1997) ‘Adam Smith’s Conception of the Social Relations of Production', European Journal of the History of Economic Thought 4 (1): 2342.

Verburg, Rudi (2000) ‘Adam Smith’s Growing Concern on the Issue of Distributive Justice', European Journal of the History of Economic Thought 7 (1): 23-44.

Watson, Matthew (2005) Foundations of International Political Economy. Basingstoke: Palgrave Macmillan.

Watson, Matthew (2006) 'Towards a Polanyian Perspective on Fair Trade: MarketBound Economic Agents and the Act of Ethical Consumption', Global Society 20 (4): forthcoming.

West, Edwin (1976) Adam Smith: The Man and His Works. Indianapolis, IN: Liberty Fund.

Weinstein, Jack Russell (2006) ‘Sympathy, Difference, and Education: Social Unity in the Work of Adam Smith', Economics and Philosophy 22 (1): 1-33.

Whatmore, Susan and Lorraine Thorne (1997) 'Nourishing Networks: Alternative Geographies of Food', in David Goodman and Michael Watts (eds) Globalising Food: Agrarian Questions and Global Restructuring, pp. 287-304. London: Routledge. 
Young, Jeffrey and Barry Gordon (1996) 'Distributive Justice as a Normative Criterion in Adam Smith’s Political Economy’, History of Political Economy 28 (1): 1-25. 